\title{
DEVELOPMENT OF SMALL AND MEDIUM BUSINESS IN UKRAINE WITH FUNDING FROM THE EUROPEAN UNION
}

\author{
Olena Parubets ${ }^{1}$, Olena Boiko², Dmytro Suhoniako³
}

\begin{abstract}
Crisis phenomena in Ukraine have led to the reduction in volumes of state financial and credit and investment support for the development of subjects of small and medium-sized business (SMB) and, as a consequence, the reduction of their export potential. Ukrainian SMB receives considerable advisory and technical assistance due to the implementation of projects and programs in the area of the EU and European financial institutions. Despite economic expediency of development of financial cooperation with European structures, a situation appears in Ukraine that SMB entities have no sufficient information about the possibility to participate in European projects and programs or the realization of the latter in full volume is impossible over bureaucratic hurdles. The purpose of the article is to study volumes and directions of SMB financing in Ukraine at the expense of EU programs, identify problems occurring in the process of obtaining external financial sources, and to develop directions of their solution. In order to achieve the set purpose, the paper solves the following tasks: to study conditions of providing financial and credit assistance to Ukrainian SMB from the EU and European financial institutions; reveal problems appearing on the way of development of financial cooperation of the SMB with the abovementioned institutions; develop recommendations in relation to the improvement of financial support tools of the SMB. Methods. In the process of the study, general scientific methods are used, namely, economic and statistical, analytical - to analyse the current state of financing of the SMB development in terms of EU projects and programs; analysis, synthesis, logical generalization - to reveal problems in the SMB external financing and areas for their elimination. Results. On the basis of conducted analysis of financial and credit assistance to Ukrainian SMB provided within the programs and projects of the EU and European financial institutions, their positive influence on the results of enterprise activities was revealed and the main problems of the development of further financial cooperation were identified. For their solution, it is proposed to use new financial instruments providing for the development of co-financing programs, the formation of venture funds, and development of financial relations within the public- and municipal-private partnership. Novelty/originality. Novelty and originality of the research carried out are in the solution of the scientific and practical problem of external financing of Ukrainian SMB from the EU and substantiation of recommendations aimed at the intensification of state and local executive authorities' participation in the development of financial cooperation with European financial institutions.
\end{abstract}

Key words: small and medium-sized business, financing, development, financial resources, loans, financial institutions.

JEL Classification: D29, G28

\section{Introduction}

The choice of European integration vector by Ukraine expands the possibilities of the exit of the SMB into the EU market; however, a significant obstacle on this way is the lack of the necessary amount of financial resources for the innovative renewal of their activities,

Corresponding author:

${ }^{1}$ Chernihiv National University of Technology, Ukraine.

E-mail: olena.parubets@gmail.com

ORCID: https://orcid.org/0000-0001-5357-7581

${ }^{2}$ Zaporizhzhia State Engineering Academy, Ukraine.

E-mail: lvbojko@yahoo.com

ORCID: https://orcid.org/0000-0002-4381-8502

${ }^{3}$ Chernihiv National University of Technology, Ukraine.

E-mail: dmytro.sugonyako@gmail.com

ORCID: https://orcid.org/0000-0002-5054-7253 the introduction of modern approaches to management. Under the deficit of state and local budgets, inflation fluctuations, and growing interest rate on loans, the access of Ukrainian SMB to financial resources is limited.

Acceleration of the integration processes of Ukraine's accession to the single economic space of the EU and 
free trade area requires the development of a competitive sector of the SMB. The latter plays a decisive role in the financial-economic and social development of the state and expansion of foreign economic activity.

Bringing the business environment of the SMB functioning to the European requirements necessitates the development of effective programs of state financial support. It is noted in the published statistical report within the Leadership in Economic Governance Program realized by the support of the United States Agency for International Development (USAID) that small and medium-sized business development is one of the priorities of state economic policy of Ukraine. Despite this, small and medium-sized enterprises' access to financing remains limited.

Expansion of SMB entities' access to cheap longterm borrowed financial resources is possible due to the participation in EU financing programs, which provide for favourable terms for the provision of funds with minimum requirements for credit security, low-interest rates, and deferred payment of principal.

Nevertheless, under the development of the digital economy, the absence of single information space of functioning of business environment predetermines the occurrence of the situation when SMB entities are not familiar with state development strategies, changes in the regulatory-legislative framework, opportunities of participation in projects and programs financed by the European Union. The abovementioned is proved by studies conducted by Ukrainian-British consulting company VimesVC, according to which about $30 \%$ of Ukrainian representatives of the SMB are not familiar with the realisation of support programs for their development. According to experts of the company, Ukrainian SMB needs essential information support, however, requests assistance very seldom. The situation is also worsened by the lack of statistical information, using which it is possible to carry out a comparative analysis of SMB development in Ukraine and EU countries in order to assess the current state and prospects of joining a free trade area. Given this, the study devoted to the analysis of cooperation of Ukraine and the EU in the area of financing of SMB development programs is relevant and timely. Research results will be useful when developing strategic measures for promoting SMB development both at the state and local levels and also for the representatives of business structures that are in need of financial resources.

\section{Literature review}

Problems of external financing of the SMB are urgent for many countries of the world, which predetermines a considerable level of scholars' interest to areas of their solution.

Studying the influence of financing programs of the European Regional Development Fund (ERDF) on the results of activities of Romanian SMB, C. Ciocoiu (Ciocoiu, 2015) has come to the conclusion that the volume of financing most correlates with the number of SMB staff, to a lesser extent - with gross profit. Also, it was concluded on the need to determine priorities when evaluating applications for grants in order to improve financing efficiency.

B. Geruzel-Dudzińska (Geruzel-Dudzińska, 2016) points to the presence of obstacles for investments in equity of the SMB both in Poland and other EU countries, the complexity of access to external financing sources, and lack of justice in their distribution.

When studying financial risks in Serbia's SMB activity, N. Stajic (Stajic, 2015) points to a low motivation of commercial banks in relation to their lending. This is a consequence of a conservative approach to the practice of SMB financing in Serbia. The author proposes to speed up the implementation of Basel III standards in the practice of commercial banks' activity in order to improve access of small and medium enterprises to lending programs.

When receiving external financing of SMEs, there is often gender inequality (Rahman et al., 2017) and also the influence of collateral on the decision of banks in relation to credit arrangement. Empirical studies show that borrowers don't want to take out loans from banks when the cost is too high.

The existing restrictions in providing an effective demand for the SMB sector financing will have substantial effects for general efficiency of economies of both developed and developing countries (Harrison \& Baldock, 2015).

State as a party interested in SMB development should contribute to the lending of the latter through the system of providing state guarantees, which is important for attracting private investors on terms that that are in line with state goals (Cusmano, 2018). According to the author, it is especially relevant for small enterprises, which have more limited access to lending over the insufficient collateral, lack of credit history, low qualification of employees drawing up financial reports. It is a mechanism of the state loan guarantee that is a widely accepted instrument of risk transference to overcome these restrictions.

Analysis of literary sources allows drawing a conclusion that despite priority of the SMB for economic development, SMB financing issues remain unresolved in most of the EU countries, as well as in Ukraine, which predetermines the relevance of this study.

\section{Study of SMB financing programs in Ukraine from the EU and European financial institutions}

The adopted Strategy for the Development of Small and Medium-Sized Enterprises in Ukraine for the period up to 2020 (Pro skhvalennia, n.d.) stressed 
the necessity of SMB development. Among the main measures, the approved plan for its implementation points to the application of such financial instruments as the expansion of crediting to small and medium-sized enterprises by commercial banks; intensification of the use of promissory notes and bills of exchange by SMB entities; development of crediting by non-bank financial institutions; reducing financing requirement due to the use of factoring, leasing, crowdfunding; attraction of funds of angel investors and use of venture capital.

It is quite difficult to implement the above measures in practice without the financial assistance for the SMB development from the EU and European financial institutions. According to data of the Delegation of the European Union to Ukraine(Delegation of the European, n.d.), about 250 projects are being implemented in our country today. For the last three years, the country has received loans from the EU amounted to 12.8 billion euro, grant assistance - 200 million euro.

In accordance with the report of the Accounting Chamber of Ukraine (Accounting Chamber, n.d.), for the period from 2014 to $01.07 .2017,300$ million US dollars and 150 million euros are attracted from the European Bank for Reconstruction and Development (EBRD), 2075 million euros - from the European Investment Bank (EIB), and 367 million euros - from Kreditanstalt für Wiederaufbau (KfW) - 367 million euros. From these funds, considerable financial and technical assistance is provided for the SMB development.

Further intensification of economic and financial cooperation on a qualitatively new basis between Ukraine and EU countries is possible due to the development of SMB enterprises and their joining the free trade area. Not only EU countries but also other world countries, which are intended to develop trade relations with the EU through Ukraine, are interested in the development of such cooperation.
In recent years, the EU is the major trade partner and investor of Ukraine. According to statistical data (State Statistics, n.d.) following the results of 2017, the export volume of Ukraine to the EU amounted to $31.5 \%$, whereas the structure of Ukrainian import in the EU was 46.0\%. The report by the USAID (USAID Ukraine, 2018), according to the results of the first half of 2017, notes that the SMB share in the EU countries' export amounted to $84 \%$, in Ukraine $-89 \%$, while the participation of these entities in the value of country's exports in the EU is at the level of $35 \%$, in Ukraine - only $15 \%$.

Given this, SMB entities in Ukraine require not only financial resources but also mastering new knowledge, skills, and abilities of business development in accordance with best European practices. In such conditions, Ukrainian business representatives can receive a considerable financing volume on the promotion of the development of innovative and export activities for projects and programs realized by the EU together with partners - European financial institutions (Table 1).

As noted in Table 1, EU4Business Initiative is financed by the EU and implemented with the help of the European Bank for Reconstruction and Development (EBRD), European Investment Bank (EIB), Kreditanstalt fur Wiederaufbau (KfW), OECD, World Bank, and other partners. For the period of 2009-2017, within the implementation of EU4Business Initiative (EU4Business, n.d.), 10 projects out of 43 foreseen by the program for the Eastern Partnership countries were implemented in Ukraine. For the period under analysis, advisory support was provided for 660 enterprises, credit one - for 1043. Due to credit support from the EU amounted to 156 million euro, credits totalling 189 million euro were provided. This allowed SMB enterprises to create 5887 new workplaces, considerably improve development prospects, increase trading volume, in particular, exports. As for new, ongoing are: 10 projects in the sphere of improving the SMB access to financing;

Table 1

EU programs for SMB development support in Ukraine

\begin{tabular}{|l|l|c|}
\hline \multicolumn{1}{|c|}{ Name of project/program } & \multicolumn{1}{|c|}{ Budget } & Duration \\
\hline EU4Business Initiative & $\begin{array}{l}320 \text { million euro, due to which 1,96 billion euro will be additionally } \\
\text { attracted in form of credits provided by partner banks to SMB }\end{array}$ & $2009-2020$ \\
\hline European Fund for Southeast Europe (EFSE) & 5,1 million euro & $2009-2019$ \\
\hline $\begin{array}{l}\text { Competitiveness of Enterprises and Small } \\
\text { and Medium-sized Enterprises (COSME) }\end{array}$ & $\begin{array}{l}2,3 \text { billion euro } \\
\text { (900 million euro for Ukraine) }\end{array}$ & $2014-2020$ \\
\hline EU4Business - EBRD Credit Line & 19,43 million euro & $2016-2026$ \\
\hline DCFTA Initiative East & 62,74 million euro & $2016-2021$ \\
\hline Women in Business programme & 5,035 million euro & $2016-2022$ \\
\hline DCFTA SME Direct Finance Facility & 10,22 million euro & $2014-2026$ \\
\hline SME Finance Facility - Phase II & 15,4 million euro & $2016-2030$ \\
\hline SME Finance Facility - Phase I & 15,3 million euro, of which 150 million euro of investments & $2010-2020$ \\
\hline $\begin{array}{l}\text { DCFTA project } \\
\text { Direct Finance Facility }\end{array}$ & $\begin{array}{l}10 \text { million euro - grant of the European Union, } \\
70 \text { million euro of investments }\end{array}$ & $2014-2024$ \\
\hline Horizon 2020 Programme & 80 million euro & $2014-2020$ \\
\hline
\end{tabular}

Source: compiled by the authors based on (Delegation of the European, n.d.), (EU4Business, n.d.). 
3 projects aimed at strengthening the regulatory framework; 3 for improving the base of knowledge and business skills of Ukrainian entrepreneurs; 1 project directed to improve market access.

The main component of COSME is to provide the SMB access to external financing through the use of such financial instruments as providing guarantees to financial and credit institutions and support for investment funds. However, delay of resolution at the state level on financing requirements has led to the suspension of implementation of the financial component of the program for Ukrainian small and medium-sized business. Loss of such a source of financial assistance for the SMB development will negatively affect indicators of its competitiveness and limit possibilities of receiving currency earnings from foreign economic activity.

In addition to the projects and programs of financial assistance for the SMB development which are noted in Table 1, European organizations provide essential advisory support on the implementation of:

- Financial Sector Institution Building and Crisis Response (2009-2018);

- Advice for Small Businesses (2010-2018);

- FORBIZ (2016-2019);

- Eastern Partnership: Ready to Trade - an EU4Business initiative (2017-2020);

- EU4BUSINESS: Network of Business Support Centres in Ukraine (2016-2020).

Due to advisory and technical support provided to Ukraine within the FORBIZ project under the EU4Business Initiative, the Strategy for the Development of Small and Medium-Sized Enterprises in Ukraine for the period up to 2020 was developed and adopted. At the level of the Ministry of Economic Development and Trade of Ukraine, PRO Platform for Effective Regulation, Better Regulation Delivery Office (BRDO) are implemented, the creation of National Agency of SMB Development in Ukraine is envisaged.

Domestic entrepreneurs can get information and advisory support in the area of the search of projects and programs of SMB development financing on the following websites and Internet portals:

- EU - website-guide "European-style business";

- EBRD - Advice for Small Businesses in Ukraine;

- German-Ukrainian Fund - support for the financing of small and medium-sized enterprises in Ukraine;

- European Executive Agency for Small and Mediumsized Enterprises;

- Ministry of Economic Development and Trade of Ukraine - PRO Platform for Effective Regulation;

- National Platform of Small and Medium Business, etc.

In spite of a considerable number of websites, SMB representatives are insufficiently informed about the possibilities of participation in lending, investment, and grant programs of the EU, use of new financial instruments in the form of converted loans, crowdfunding over the lack of single information space.
This makes innovation and investment development of SMB enterprises impossible and leads to borrowing mainly for the needs of replenishment of working capital and financing of investment projects at their own expense.

\section{Identifying research problems and developing ways to solve them}

Key problems on the way towards the effective introduction and implementation of SMB financing programs from the EU and European financial institutions are as follows:

- the existence of bureaucratic corruption at the stages of social product distribution;

- non-conformity of indicators of financial and economic development of Ukraine and SMB enterprises with the minimum requirements of European financial institutions;

- introduction of temporary currency restrictions by the National Bank of Ukraine;

- delay in carrying out of key reforms, in particular, financial decentralization reform;

- protraction of the process of adopting the necessary legislative acts, in particular, in the sphere of promoting the SMB crediting development and protecting the rights of creditors and investors;

- the absence of developed business and information infrastructure for the support of SMB development;

- low level of interaction and confidence of SMB entities in the banking system, which in most cases serves as a mediator when receiving financing on the part of European funds and programs;

- the high share of troubled loans in the total of credits in the total portfolio of Ukrainian banks;

- non-transparency of the use of funds of financialcredit and grant support by the EU and European financial institutions.

Based on studying the experience of the EU member states, we propose the following directions to solve SMB financing problems:

- creation of state and municipal funds for supporting the SME development;

- state support for the formation and development of free trade areas, clusters;

- development of decentralization processes in the field of state regulation of the SMB development financial provision;

- strengthening the cooperation of state and local authorities with European financial institutions and organizations, in particular, the German-Ukrainian Fund in terms of co-financing of SMB financing programs;

- strengthening the control on the part of public institutions over the timely fulfilment and repayment of debt obligations by SMB entities and target use of funds borrowed from European financial institutions. 


\section{Conclusions}

Study of the SMB financing programs in Ukraine by the EU and European financial institutions allowed revealing not only the positive influence of financial, credit, investment, and grant assistance on performance indicators of SMB enterprises but also identifying a number of problems hampering the intensification of development of financial cooperation processes. Key among them are corruption, delay in conducting reforms, and adopting laws and regulations, as well as the lack of system and consistent financial support for the SMB development on the part of the state, limited access to external financing, absence of banks' motivation for lending to Ukrainian business because of permanent growth of interest rate, increasing level of risks of non-return loans. In total, the abovementioned problems lead to innovative backwardness and reduction of export potential of Ukrainian small and medium-sized enterprises.

It is the state financial support for the SMB that is a guarantee of their further efficient development and improvement of Ukraine's public image in the world. In relation to this, further development of the SMB in
Ukraine requires the development of not only publicprivate but also a municipal-private partnership.

Taking into account the positive experience of EU countries towards the SMB financial support, it is necessary to develop a partnership of state and local authorities and local self-government bodies with the representatives of business structures with the help of applying modern financial instruments. They include conversion loans, the creation of coinvestment institutions, share investment venture funds, crowdfunding. For this purpose, at the state level, it is necessary to provide for the transparency of fund market, stability of the banking system, improvement of investment climate, to refund part of costs of the SMB investment projects aimed at their innovative update at the expense of public or municipal funds, providing preferences for the payment of state and local taxes and fees. This will enable to develop and implement transparent and effective mechanisms of financial and credit support for the SME development on the basis of broadening of cooperation of state and local executive authorities and local self-government with business structures and financial institutions of the EU taking into account best European practices.

\section{References:}

Accounting Chamber of Ukraine (n.d.). Retrieved August 28, 2018, from: http://www.ac-rada.gov.ua/doccatalog/ document 16753343/Zvit_19-7_2017.pdf?subportal=main

Basel III: international regulatory framework for banks. Retrieved August 30, 2018, from: http://www.bis.org/bcbs/ Ciocoiu, C. (2015). The impact of the European regional development fund on smes - evidence from Romania Annals of the University of Oradea. Economic Science, 25(1), 525-532.

Competitiveness Small and Medium Enterprises (2014). Retrieved August 28, 2018, from: http://cosme.me.gov.ua/ Cusmano, L. (2018). SME and Entrepreneurship Financing: The Role of Credit Guarantee Schemes and Mutual Guarantee Societies in supporting finance for small and medium-sized enterprises. OECD SME and Entrepreneurship Papers, 1, OECD Publishing, Paris. doi: 10.1787/35b8fece-en

Delegation of the European Union to Ukraine (n.d.). Retrieved August 28, 2018, from: https://eeas.europa.eu/ delegations/ukraine_uk

EU4Business (n.d.). Retrieved August 28, 2018, from: http://www.eu4business.eu/uk/about

Geruzel-Dudzińska, B. (2016). Financing of Fixed Asset Investment in the Small and Medium-sized Enterprises in Poland. Contemporary Economy, 7(1), 71-80.

Harrison, R., Baldock, R. (2015). Financing SME growth in the UK: meeting the challenges after the global financial crisis. Venture Capital, 17(1-2), 1-6. doi: 10.1080/13691066.2015.1050241/

Rahman, A., Rahman, T., Belas, J. (2017). Determinants of SME Finance: Evidence from Three Central European Countries. Review of Economic Perspectives, 17(3), 263-285. doi: 10.1515/revecp-2017-0014

Rozporiadzhennia "Pro skhvalennia Stratehii rozvytku maloho i serednoho pidpryiemnytstva v Ukraini na period do 2020 roku" [Order "Strategy for the development of small and medium enterprises in Ukraine up to 2020"]. Retrieved August 28, 2018, from: http:// zakon2.rada.gov.ua/laws/show/504-2017-\%D1\%80

Stajic, N. (2015). Corporate strategy of Serbia's SMEs in working capital financial risk management. Economics Theory and Practice, $8(1), 1-15$.

State Statistics Committee of Ukraine (n.d.). Retrieved August 28, 2018, from: http://www.ukrstat.gov.ua USAID Ukraine (2018). Retrieved August 28, 2018, from: https://www.usaid.gov/uk/ukraine 